\title{
Free Movement of Workers as an Instrument of Creation of the European Common Market
}

\section{Agata Ludera-Ruszel}

University of Rzeszow, 4-5 Ofiar Getta Street, Rzeszow, Poland

$\Gamma$ Crossef http://dx.doi.org/10.5755/j01.eis.0.9.12804

The creation of common market was based on four fundamental freedoms. These freedoms have remained the central issue of the EU, although their perception has significantly changed since the Treaty of Paris. The principle of free movement of workers, as a part of free movement of persons, facilitates the mobility of workers within the EU, as any citizen of EU member states is allowed to go to another member state for work, having the same workplace rights as the nationals. The principle of free movement of workers is associated with the lack of any discrimination between workers based on nationality, which is guaranteed by EU legislation. For these reasons, that principle at the same time remains one of the most controversial issues of the European integration. It is so because from the beginning of its existence, its realisation has required the necessity to reconcile - sometimes different - national interests for the sake of common market. Due to the significant disparities between member states regarding their economic status and standard of living, the principle of free movement of workers is often associated by the highly developed countries with the inflow of cheap labour force from the poorer member states that poses a real threat for its national labour markets and welfare systems.

Considering the above mentioned facts, the article solves the research problem: to determine the place of the principle of free movement of workers in the process of creation of the European common market. The aim of this paper is to present the decisive stages in changing the perception of the principle of free movement of workers through the process of European integration.

To achieve this aim, the main tasks are: to present free movement of workers at the beginning of European integration, the perception of free movement of workers at the struggle to implement the idea of EU citizenship, the perception of free movement of workers at the time of EU enlargements and the impact of the economic crisis of 2008+ on the realisation of free movement of workers.

The paper presents a combination of several research methods: comparative analysis of international scientific works; comparative analysis and interpretation of the EU legal documents, strategies and practical papers as well as the analysis of the CJEU decisions in cases that involve the free movement of workers.

The results of the article are: explanation of the emergence of the idea of free movement of workers at the beginning of European integration, presentation of the development of free movement of workers due to the implementation of the idea of EU citizenship, indication of the manner of implementation of free movement of workers for new member states, the way of realisation of free movement of workers at the time of economic crisis of 2008+.

KEYWORDS: European integration, European Union, free movement of workers, common market, legal regulations, EU citizenship.

\section{Abstract}

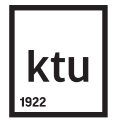

European Integration Studies No. 9 / 2015

pp. $161-169$

DOI 10.5755/j01.eis. 0.9.12804 (C) Kaunas University of Technology 
The idea of common market without internal frontiers laid the foundation for the European integration, which resulted in the creation of the European Union (EU) (Schwarze, 2006, p. 91). The common market was seen as a mechanism that would lead to peaceful and prosperous Europe after the Second World War (Touzenis, 2012, p. 15). For a long time, European integration and the idea of common market have been mostly focused on economic goals, which have a predominant position over social issues (Perulli, 2014, pp. 33-34). The struggle towards accelerated raising of the standard of living has been subordinated to economic integration within the European Coal and Steel Community (ECSC) and the European Economic Community (EEC)'. The social goals would be achieved through the harmonious economic development: they would be the result of the existence of the common market (Carson, 2004, p. 3).

The primary idea of European integration - the creation of common market, has been based on four fundamental freedoms, which have been introduced through European Community regulations. These are: the freedom of goods, the freedom of workers, the freedom to provide services and the free movement of capital. The importance of these four freedoms for the common market has been indicated by the Court of Justice of the EU (CJEU), which stressed in the Gaston Schul case that the common market "involves the elimination of all obstacles to-intra Community trade in order to merge the national market into a single market bringing about conditions as close as possible to those of a genuine internal market"2. For these reasons, those four freedoms have remained the central issue of the EU, although their perception has significantly changed since the Treaty of Paris. Since the beginning, the European integration has taken on more social dimension, those four freedoms have started to be perceived not only through their economic goals but also through the social ones (Shaw, 2005). This is particularly true of the free movement of workers, which due to European integration, has been extended to all persons - the citizens of the EU. The principle of free movement of workers, as part of free movement of persons, facilitates the mobility of workers within the EU, as any citizen of the EU member states is allowed to go to another member state for work having the same workplace rights as the nationals (Gordon, 2011, p. 3). The principle of free movement of workers is associated with the lack of any discrimination between workers based on nationality, which is guaranteed by EU legislation. For these reasons, that principle at the same time remains one of the most controversial issues of the European integration. It is so because from the beginning of its existence, its realisation has required the necessity to reconcile - sometimes different - national interests for the sake of common market.

Considering the above mentioned facts, the aim of the article is to solve the research problem: to determine the place of the principle of free movement of workers in the process of creation of the European common market. There are many scientific works analysing the process of European integration from different perspectives. This article will significantly contribute to the studies that focus on the evolution of European integration with regard to the principle of free movement of workers ${ }^{3}$.

1 See Article 2 of the Treaty constituting European Coal and Steel Community (hereafter referred to as the Treaty of Paris) from 1951 and the Treaty establishing the European Economic Community (hereafter referred to as the Treaty of Rome) from 1957, both signed by six countries: Belgium, the Netherlands, Italy, France, the Republic of Germany, and Luxembourg.

2 The case C-461/03 Gaston Schul Douane-expediteur BV v Minister van Landbouw, Natuur en Voedselkwaliteit, [2005] ECR I-10513.

3 See A. Favell (2008), Eurostars and Eurocities. Free Movement and Mobility in an Integrating Europe, UK, Blackwell Publishing; S. Giubboni (2007), Free Movement of Persons and European Solidarity, in: European Law Journal, Vol. 13, Issue 3, pp. 360-379; J. Handoll (1995), Free Movement of Persons in the UE, New York, John Wiley\&Sons; W. Maas (2005), Freedom of Movement Inside 'Fortress Europe', in: Global Surveillance: Borders, Security, Identity, ed. E. Zureik, M.B. Salter, Devon, UK, Willan Publishing; S. O'Leary (1996), The Evolving Concept of Community Citizenship: From the Free Movement of Persons to Union Citizenship, The Hague, Kluwer Law International; E. Spaventa (2007), Free movement of persons in the EU. Barriers to movement in their constitutional context, Alphen aan den Rijn, Kluwer Law International; F. Weiss, F. Wooldridge (2002), Free Movement of Persons Within the European Community, Kluwer Law International, The Hague. 
The aim of this paper is to present the decisive stages in changing the perception of the principle of free movement of workers through the process of European integration.

To achieve this aim, the main tasks are: to present free movement of workers at the beginning of European integration, the perception of free movement of workers at the struggle to implement the idea of EU citizenship, the perception of free movement of workers at the time of EU enlargements and the impact of the economic crisis of 2008+ on the realisation of free movement of workers.

The paper presents a combination of several research methods: comparative analysis of international scientific works; comparative analysis and interpretation of the EU legal documents, strategies and practical papers as well as the analysis of the CJEU decisions in the cases that involve the free movement of workers.

As mentioned before, the early beginnings of the European integration fell on hard times of recovering after the Second World War. Therefore, the struggle to make the vision of peaceful and prosperous Europe come true strongly determined the nature and direction of the process that resulted in the creation of the European Economic Community in 1957, as the predecessor of the EU. Hence the idea of Europe as an area without internal borders emerged. The principle of free movement of workers, as one of the four 'pillars' of European common market, has been supported as an instrument to facilitate economic growth (Smigiel, 2010, p. 1). The labour shortages which Europe was experiencing at that time were seen as a real threat to the economic development (Castles and Miller, 2003). It is therefore not surprising that the free movement of workers was initially targeted at workers and only later at the economically active population and other groups of EU citizens.

Looking way back to the beginnings of the European integration, the principle of free movement of workers was not, however, the key point in the negotiations between the six countries - the founders of the ECSC. The decision to take free movement of workers into consideration was initiated by Italy, which saw it as an 'attractive' instrument to "export its surplus labor" in order to reduce high unemployment (Mason, 1995, p. 5) and as a tool to improve working conditions of a wide group of nationals who had already worked abroad, mostly in Belgium (Romero, 1993, p. 54). For these reasons, the acceptance of free movement of workers was a precondition of supporting the idea of European integration by the Italian government (Pella, 1956). As a result of large-scale promotion, the free movement of workers in coal and steel industries was finally included in the ECSC Treaty, with the acceptance of other member states, especially Germany and Netherlands, that similarly were "labour-exporting countries" (Maas, 2005, p. 1013). In order to facilitate the creation of the ECSC as an economic community as much as possible, the area of free movement of workers within the ECSC was tailored to coal and steel industries, as only the workers with recognized qualifications for positions in such industries benefited from them. However, the Italian government did not succeed in the reception of a broad interpretation of the definition of 'recognized qualifications'. As a result, only part of the coal and steel workers in the Community were entitled to receive work permissions that allowed them to move to other member states. That became a compliment to those member states, especially France and Luxembourg, which were seriously concerned that significant labour migrations would not cover their real demand for coal and steel workers. Moreover, member states received a relatively large margin of appreciation when implementing that principle due to the possibility of derogation from the realisation of free movement of workers subject to the fundamental needs of health and public order.

The reduced demand for coal and steel workers triggered heated debate within the ECSC over the idea of creation of a more general market for labour, not limited to coal and steel workers. The idea of the creation of an economic common market based on free movement of workers was perceived as a response to the existing practice of bilateral recruitment agreements, which

Free
movement
of workers -
the creation
of common
market for
labour


were concluded between Germany, Italy and France in the period of 1945-1955 (Favell, Recchi, 2009 , p. 5). Yet, the Treaty of Rome, which established the EEC, provided a solid legal framework for the creation of common market for labour, as it extended the scope of the principle of free movement to all workers, with the only exception of those employed in the public service. The members states, however, preserved their competence to introduce limitations that would be justified on the grounds of public policy, public security and public health. Moreover, in contrast to the ECSC, the Treaty of Rome transferred the competences regarding the free movement of workers to the European Community.

As the European integration surged forward, the social issues were steadily growing in importance. They were no longer subordinated to economic targets but 'step by step' identified as an independent goal. The process of attributing a much stronger social dimension to the European Community also involved the free movement of workers. The development of the idea of EU citizenship was decisive for the realisation of free movement of workers (Pieter Van der Mei, 2003, p. 27). The free movement of workers has become associated with the idea of the establishment of EU citizenship ${ }^{4}$, thus it has been considered, not only in terms of movement of labour as a factor of production but in terms of a fundamental individual right (Evans, 1982, p. 498), which has produced a direct legal effect ${ }^{5}$ affecting both the host and the home state ${ }^{6}$. As a result, together with consistent development of the common social policy and the idea of European citizenship, the principle of free movement has been, therefore, gradually extended to the other groups of the $\mathrm{EU}$ and has covered the broad spectrum of social and economic rights to which every national of a member state is entitled. The Charter of the Fundamental Rights adopted in 1989 had a great importance in this respect, despite its non-binding nature?. It was, however, until 1993, when the Maastricht Treaty finally finished the process of widening the freedom of movement to cover all EU citizens (Henry and Pastore, 2014, p. 166).

The role of the ECJ in the process of establishing EU citizenship, as well as the whole common social policy, is undeniable. The impact of the ECJ has been twofold. Since 1970, the ECJ has consistently representing broaden scope of interpretation of the relevant primary and secondary legislation related to the free movement of workers, e.g. with regard to the principle of equal treatment of workers that has been referred not only to the labour market but also to the other aspects of workers' social life (Baldoni, 2003, p. 8) ${ }^{8}$. In the case $32 / 75$ Cristini $^{9}$ and in C-261/83 Castelli', the ECJ adopted a broad meaning of the concept of 'social and tax advantages' to which every worker-national of a member state is entitled to, according to Article 7(2) of the Regulation No 1612/68", which has been extended to mean "all social and tax advantages which, whether or not attached to the contract of employment, are generally granted to national workers primarily because of their objective status as workers or by virtue of the mere fact of their residence on the national territory and the extension of which to workers who are national of other member states therefore seems suitable to facilitate their mobility within

\footnotetext{
4 See ECJ in the case C-85/96 Martínez Sala vs Freistaat Beyern [1998] ECR I-2691 and in the case C-184/99 Grzelczyk vs Centre Public d'Aide Social [2002] ECR I-6153 in which the ECJ pointed out that "Union citizenship is destined to be the fundamental status of nationals of the member states".

5 See ECJ in the case 167/73 Commission v. France [1974] ECR 359, 41 and in the case 41/74 Van Duyn [1974] ECR 13337, 6-7.

The ECJ case 41/74 van Duyn [1974] ECR 1337 and the case C-384/93 Alpine Investments [1995] ECR I-1141, 30.

7 The Lisbon Treaty, adopted on 1st December 2009, then gave the Charter of Fundamental Rights legally binding force.

8 See also ECJ in the case O'Keeffe [1998], 20-25.

9 [1975] ECR 1085, 12-13.

10 [1984] ECR, 3199.

11 Regulation No 1612/68 of the Council of 15 October 1968 on freedom of movement for workers within the Community, O.J. UE. L. 257 of 19/10/1968, p. 2. This Regulation has been(można opuścić)
} 
the community"12. Simultaneously, the ECJ has systematically shifted the gravity of freedom of movement from workers to all nationals of member states. As a result, in 1970 the freedom of movement covered the self-employed ${ }^{13}$, while since the 1980s it has been extended to persons who take up paid apprenticeship ${ }^{14}$, who enter university in a different member state after having taken up professional activity ${ }^{15}$, and seasonal workers ${ }^{16}$. Finally, in the joint cases C-502/01 and C-31/02 Gaumain-Cerri and Maria Barth ${ }^{17}$, the ECJ based the EU citizenship on the principle of non-discrimination on the grounds of nationality, which is decisive for the effective realisation of free movement of workers, by stating that "EU citizenship enables all nationals of the member states to enjoy the same treatment in law".

Since its creation, the European Community, and later the EU, has been enlarged six times. The adoption of new member states has often tested the resistance of the principle of free movement of workers. However, it might seem that the fear usually resulting from unlimited exercise of free movement of workers in 'new' member states has emerged, not only in the case of accession of the poor ones. As for the first enlargement in 1973, involving the UK, Denmark and Ireland, it caused the concerns of France and the Netherlands about the risk of labour market destabilization resulting from a high level of immigration (Guild, 2004, p. 189). Those fears, however, may be partly explained by the oil crises of 1973-1974 in Arab countries that shook up the European economy and 'closed the door' for migrant workers (Power, 1979, p. 5). Although, in that time, like in 1995 (the accession of Austria, Finland and Sweden), any time restrictions on the exercise of the free movement of workers were introduced by the 'old' member states.

There five times, however, when the admission of new member states put the free movement of workers on the top of the really heated debate in Europe. In those cases the national interest triumphed over the project of building a united Europe, when the so-called "European solidarity" was severely put to the test. It occurred for the first time in 1981, at the time of Greece's accession, and afterwards, in 1986, due to the Spanish and Portuguese membership. Later it happened in 2004 and 2007 due to the EU enlargement with the ten relatively low-wage Eastern and Central European countries of the Czech Republic, Estonia, Lithuania, Latvia, Poland, Slovakia, Slovenia, Hungary ("A8"), Romania, Bulgaria, and recently in 2013, at the time of Croatia's accession to the EU. The controversy that arose over the principle of free movement of workers was related to the fact that it was often associated by the 'old' member states with the ghost of so-called 'welfare migration', that is the inflow of usually cheap labour force from the newly joined member states that poses a real threat for their national labour markets and welfare systems (Vilcu, 2014, p. 1). The free movement of workers was then perceived as a danger to economic and social stability. The predicted 'wave of migration' was estimated to be high because of significant disparities in income and standard of living between 'old' and 'new' member states. Therefore, the realisation of free movement of workers was each time a central issue during the accession negotiations. In order to protect the 'stability' of their labour markets, the 'old' member states have decided to introduce transitional limitations on free movement of workers concerning the 'new' member states.

12 See also the case 207/78 Even [1979] ECR 2019, 22 and C-249/83Hoeckx [1985] ECR 973, 20. Previously the ECJ had represented a strict way of interpretation of the term 'social advantages' as those related only to the rights and benefits connected with employment - e.g. case 76/72 Michel S. [1973] ECR 457, 9.

13 The ECJ case C-268/99 Jany and others v. Staatssecretaris van Justice [2001] ECR I-8615.

14 The ECJ case 66/85 Lawrie-Blum [1986] ECR 2121.

15 The ECJ case 197/86 Lair [1988] ECR 3161.

16 The ECJ case 357/89 Raulin [1992] ECR I-1027.

17 [2004] ECR I-06483.

\section{Free movement of workers - a fear of 'social tourism' at the time of EU enlargements}


Germany ${ }^{18}$, and later also Austria, played a leading role in this 'battle' (Nyman-Metcalf, 2002, p. 1). It is not surprising, however, that some regard this process as the formation of the so-called 'second class citizenship' (Kochenov, 2004). At the time of Greek, Spanish and Portuguese accession, the transitional period of seven years was finally introduced. However, as it became clear that the initial fears had been strongly exaggerated, as the number of nationals from those countries moving into the EU labour market was minimal, that period was shortened by one year (Baldaccini et al., 2007). Nevertheless prior “southern' experiences ${ }^{19}$, the transitional period has been repeated at three later enlargements, even though the European Commission recommended the 'old' member states to open their labour markets unconditionally. The ' $2+3+2$ formula' that was adopted in the $2004^{20}, 2007$ and 2011 Accession Treaties represents a compromise for the countries, especially Germany and Austria, which opted for the maximum seven years' transitional period. It is no surprise that Germany and Austria were the only countries which decided to maintain the maximum transitional period for countries from the A8 group, even though the last two years could only be maintained in a special case, if opening-up the labour market could lead to a serious disturbance or a threat. With respect to Romania and Bulgaria, also Belgium, France, Italy, Luxembourg, the Netherlands, Spain, the UK and Malta have decided to close their labour markets for a seven years' period as the fear of massive influx of immigrants was bolstered by the income inequalities between them, greater than ever. Among those countries was also Ireland; however, due to the European Commission report from 2011 calling for the re-assessment of functioning of the transitional limitations on their labour markets, it finally decided to remove those restrictions as of $1^{\text {st }}$ January 2012, when it was clear that the initial negative scenario was not confirmed. However, other member state, which decided to maintain the restrictions for the second phase, did not follow it, although they cannot currently present any credible evidence that opening their labour markets before the final term would be detrimental for their labour markets (Vilcu, 2014, pp. 7-8). As far as Croatia is concerned, thirteen countries decided to introduce the first two years of restrictions; these are mostly the 'old' member states, except Malta, Cyprus and Slovenia. Time will show whether prejudice, not real danger, will prevail and they decide to extend the transitional period by the next two, or even three, years.

Free movement of workers as a challenge at the time of economic crises $2008+$
The realisation of free movement of workers became a burning issue every time when Europe was experiencing some economic difficulties. As past experiences has shown, the migrant workers were at usual hit first and hardest on the labour market during economic downturns (OECD, 2009 , p. 12). That is also the case since the second half of 2008 , at the beginning of the economic crisis, when the lower demand for work could be observed (European Commission, 2012, p. 255). At this time, the EU internal migrant workforce reached the high number of 14 million compared to 43 million of foreign-born migrant population in the 27-EU (Eurostat, 2008). The member states faced the challenge to tackle this phenomenon in the context of economic crisis, although at that time overall net migration decreased. The most visible and radical example of actions taken was provided by Spain and United Kingdom (UK). The Spain was in the group of countries severely affected by the economic crisis. The country experienced a drastic fall in GDP (-3.9\%) and rise in unemployment (over 20\%). As a result, Spain, which initially opened its

18 However, Germany supported the Greek accession to the Community, with a view to strengthening the existing trade links between those countries.

19 The European Commission pointed out that "Experience of past enlargements shows that emigration diminishes rather than increases after enlargement", in: Free Movement of Workers to and from the New Member States - How will it work in Practice? http://europa.eu.int/comm/employment social/free movement/en2-pr-pdf.pdf (12/02/2015).

20 Except Cyprus and Malta, to which the time restrictions were not applied. However, in the case of Malta, the Accession Treaty included a safeguard clause, according to which this country may restrict the access to its labour market at any time within a seven years' period. 
labour market for Romanian workers from 1st January 2009 (after the first phase of the maximum seven years' period), was the first one to invoke (in the letter to the European Commission of $28^{\text {th }}$ July 2011) on the 'safeguard clause' that enables to re-impose restrictions on the free moment of workers on the grounds of undergoing or foreseeing serious labour market disturbances. The European Commission approved this request and temporary restrictions (until 31st December 2012) concerning Romanian workers on its labour market were introduced. The UK plans to curb workers immigration, due to the predicted inflow of Romanian and Bulgarian workers after the 1 of January 2014, were on the other hand, not the result of a real threat to its economy but the part of a political strategy at the time of government election. As a result a domestic reforms aimed at restricting EU foreigners access to social benefits has been announced by UK Prime Minister David Cameron in November 2013. It was in line with the previous ECJ Dano-ruling ${ }^{21}$ in which ECJ set limits to a EU citizen's right to equal treatment when claiming social assistance from a host Member State.

Due to the economic crisis, migrant workers have many times found themselves in a really hard position on the labour market, contrary to nationals from the member states. The worse position of migrant workers was the result of interaction of a number of different factors. However, it has to be noted that the occurrence of most of those factors is, in fact, not closely related to the economic crisis, which only accelerated their negative effects and worsened the - already not good - situation of migrant workers on the labour market. These factors were the result of prejudices and discrimination against migrant workers on the basis of their nationality, considered to be one of the main obstacles to the development of free movement of workers. It is emphasized, first of all, that migrant workers were overrepresented in the sectors that are more sensitive to the business circle, and therefore were first of all hit by the economic crisis, especially in the construction and manufacturing sector. Secondly, they were concentrated among low-skilled workers (even if their real qualifications were higher) who were easier to replace. Secondly, they were more often in temporary arrangements considered as less secure in comparison to open-ended contracts, which has caused double-side effect on its position. They were usually the first to be dismissed at the time of decrease in demand for labour, as temporary contracts allow for easier and cheaper termination, and were more often covered by the reduced working time schemes aimed at the retrenchment of labour costs (Ghosh, 2013, pp. 70-71). Moreover, the economic crisis that resulted in a rise of unemployment in many member states has lead to stronger protectionism and nationalistic course towards their national labour markets compared to pre-crisis times, that as was proved has been partially authorized by the ECJ. As a result, migrant workers were even more exposed to unequal competition in relation to nationals from member states. Due to the difficulty regarding full integration with labour markets of some member states, they were then exposed to a greater risk of poverty and social exclusion. It is, therefore, not surprising that the fight with discrimination on the ground of nationality has fallen within the scope of the EU's 'recovery' action after the time of crisis. The proposal of a new EU directive, launched by the European Commission on 26 April 2013, to improve the application of workers' right to work in another member state, was based on the conviction that a range of discriminatory practices and obstacles which EU migrant workers still face affect their right to exercise the free movement within the EU.

The principle of free movement of workers has a long history in the process of European integration, with its initial idea of creating a common market without internal borders. Undoubtedly, the free movement of workers, along with other freedoms, has been a 'pillar' of European integration which, however, has shaped the free movement of workers and determined the way

\section{Conclusions}

21 Case C-333/13 of 11 Novemner 2013 [2014] 2358. 
of its perception. The decisive stages in the changing perception of the principle of free movement of workers have, therefore, to some extent coincided with the directions of the European integration. In this regard, as the European integration has surged forward, free movement of workers has evolved from the strictly economic measure which would facilitate the economic development of member states, to a fundamental individual right that has been a significant component of the idea of EU citizenship. At the same time, the free movement of workers has been particularly sensitive to the processes that have strongly influenced the process of European integration. As the past experiences have shown, the free movement of workers was on the top of European agenda at each EU enlargement, especially in 2004 and 2007, when it made the 'old' member states sense the threat of so-called 'social tourism' and 'welfare migration', as well as due to the economic crisis of 2008-2010.

It is always difficult to predict the future. The same is true in the case of European integration and the free movement of workers. It has to be emphasized, however, that the free movement of workers must begin to be perceived as a useful instrument to respond to the issues related to the mismatches in supply and demand on the labour market, which are experienced by EU member states (Quintini, 2011, p. 4), and in the long run may become a real threat to the European economy. However, to turn it into reality, more effective fight against discrimination on the grounds on nationality is significantly important, as the prejudice and discrimination of migrant workers has become a crucial obstacle to their free movement within the EU.

\section{References}

Baldaccini A., Guild E., Toner H. (2007), Whose Freedom, Security and Justice? EU Immigration and Asylum Law and Policy, Hart Publishing, USA.

Baldoni E. (2003), The Free Movement of Persons in the European Union: A legal-historical Overview. State of the Art Report, PIONEUR Working Paper No. 2 - July, pp. 1-19.

Carson M. (2004), From common market to social Europe? Paradigm Shift and industrial change in European Union policy on food, asbestos and chemicals, and gender equality, Acta Universitatis Stokholmiensis, Stockholm Studies in Sociology N.S. 22, Stockholm University.

Castles S., Miller M. J. (2003), The Age of Migration, Guilford Press.

European Commission (2012), Employment and Social Developments in Europe 2011, Luxembourg: Publications Office of the European Union.

Eurostat (2008), Population and Social Conditions, Statistics in Focus 98/2008:

www.http://epp.eurostat.ec.europa.eu/cache/ITY OFFPUB/KS-SF-08-072/EN/KSSF-08-072-EN.PDF.

Evans A.C. (1982), European Citizenship: A Novel Concept in RRC Law, The American Journal of Comparative Law, Vol. 32, No. 4, pp. 497-515. http://dx. doi.org/10.1111/j.1468-2230.1982.tb02491.x

Ghosh B. (2013), The Global Economic Crisis and the Future of Migration: Issues and Prospects. What Will
Migration Look Like in 2045?, PALGRAVE MACMILLAN, Great Britain.

Gordon J. (2011), Free movement and equal rights for low-wage workers? What the United States can learn from the new EU migration to Britain?, UC Barkley Law School, Chief Justice Earl Warren Institute on Law and Social Policy, Issue Brief (May 2011), pp. 1-20.

Guild E. (2004), The Legal Elements of European Identity. EU Citizenship and Migration Law, Kluwer Law International.

Henry G., Pastore F. (2014), The Governance of Migration, Mobility and Asylum in the EU: A Contentious Laboratory, in: Imagining Europe: Towards a More United and Effective EU, N. Tocci (ed.), Roma, pp. 163-198.

Kochenov D. (2004), European Integration and the Gift of the Second Class Citizenship, Paper presented at the annual meeting of the International Studies Association. Le Centre Sheraton Hotel, Montreal, Quebec, Canada 17-20 March 2004.

Maas W. (2005), The Genesis of European Rights, Journal of Common Market Studies, Vol. 43, No. 5, pp. 1009-1025. http://dx.doi.org/10.1111/j.14685965.2005.00606.x

Mason J.L. (1955), The European Coal and Steel Community: Experiment in Supranationalism, The Hague: Martinus Nijhoff. http://dx.doi. org/10.1007/978-94-015-7555-3 
Nyman-Metcalf K. (2002), Free Movement of Workers and EU Enlargement: A Fundamental Freedom with Exceptions?, Swedish Network for European Studies in Economics and Business, http://www. snee.org/filer/papers/119.pdf (12.02.2015).

OECD (2009), International Migration Outlook, OECD Publishing.

OECD, European Commission (2014), Matching economic migration with labour market needs in Europe. Policy Brief, OECD Publishing.

Pella G. (1956), La Comunita Europea del Carbone e dell'Acciaio: Risultati e Prospettivo, Roma: Edizioni 5 Lune.

Perulli A. (2014). Fundamental Social Rights, Market Regulation and EU External Action, International Journal of Comparative Labour Law and Industrial Relations, Vol. 30, p. 34.

Pieter Van der Mei A. (2003), Free Movement of Persons within the European Community. Cross-Border Access to Public Benefits, Hart Publishing, Oxford.

Power J. (1979), Migrant Workers in Western Europe \& The United States, Biddles Ltd, Guildford, Great Britain.

Quintini G. (2011), Over-Qualified or Under-Skilled: A Review of Existing Literature, OECD Social, Employment and Migration Working Papers, No. 121, OECD Publishing, p. 4.
Recchi E., Favell A. (2009), Pioneers of European Integration. Citizenship and Mobility in the EU, United Kingdom, MPG Books Group. http://dx.doi. org/10.4337/9781849802314

Romero F. (1993), Migration as an Issue in European Interdependence and Integration: The Case of Italy, in: The Frontier of National Sovereignty - History and Theory 1945-1992, London, Routledge, pp. 33-59.

Schwarze J. (2006), The Development of the European Union from a common market to a political union, Ritsumeikan Law Review, No 23, pp. 91-98.

Shaw Jo. (2000), Social Law and Policy in an Evolving European Union, Hart Publishing, Oxford.

Smigiel J. (2010), Free movement of workers in the European Union. Obstacles to EU labour mobility and possibilities to overcome them, MA dissertation, Central European University.

Touzenis K. (2012), Free movement of persons in the European Union and Economic Community of west African States. A comparison of law and practice, Unesco Migration Studies 4.

Vilcu R. (2014), Labour mobility in the European Union. Transnational Arrangements and Freedom of Movements. A Romanian case study, KU Lueven, Master of European Studies: Transnational and Global Perspectives, Centre for European Studies, pp. 1-30.

\section{AGATA LUDERA-RUSZEL}

\section{$\mathrm{PhD}$}

Adjunct at Department of Law and Administration of University of Rzeszow and Judge Assistant in Appeal Court in Rzeszow

\section{Address}

4-5 Ofiar Getta Street, Rzeszow, Poland

E-mail: aruszel@ur.edu.pl

\section{About the author}

